Dual energy X-ray absorptiometry 法を用いた 慢性関節リウマチの骨塩量の検討

一咼塩量と CD45RA 陽性 CD4 細胞の関係—

$$
\begin{aligned}
& \text { 渡部一郎・佐 川昭 -天崎吉晴 - 渥美達也 } \\
& \text { 浄土智 -中林透 - 向井正也・藤咲淳 } \\
& \text { 中川昌一・永尾一彦* }
\end{aligned}
$$

Jpn. J. Clin. Immun., 14 (3) : 353 357, 1991.

\title{
Bone mineral density in rheumatoid arthritis by dual energy $\mathrm{X}$-ray absorptiometry
}

\author{
Ichiro Watanabe, Akira Sagawa, Yoshiharu Amazaki, Tatsuya Atsumi, \\ Satoshi Jodo, Tohru Nakabayashi, Masaya Mukai, Atsushi Fujisaku, \\ Shoichi Nakagawa and Kazuhiko Nagao*
}

The Second Department of Internal Medicine and *The Department of Nuclear Medicine, Hokkaido University

\section{【Summary】}

Rheumatoid arthritis (RA) was associated with generalized as well as periarticular osteoporosis. Bone mineral density (BMD) was measured by dual energy X-ray absorptiometry in 53 female patients with RA. We investigated BMD of lumbar (II-IV) and radius, the BMD corrected by age-matched female, total bone mineral (TBM) and TBM/ total lean mass. The BMD of lumbar did not correlate with the disease stage, the activities and the laboratory findings. But the BMD of radius and total body was lower in stage IV than in stage I - III and it was also lower in patients with low grasping score. In laboratory findings, the BMD was lower in patients with decreased CD45RA + CD4 cells and/or increased CD8 $+\mathrm{HLA} \cdot \mathrm{DR}$ cells. This data suggested that there was a association between the abnormal function of lymphocytes and the osteoporosis in RA.

Key words : rheumatoid arthritis, dual energy X-ray absorptiometry, osteoporosis,

CD45RA 


\section{【概 要】}

慢性関節リウマチ（以下 RA）は，関節周囲以外の全身性の骨粗籍症も報告されている，われわれは dual energy X-ray absorptiometry（DEXA 法）を用い 53 例の女性 RA 患者の骨塩量を測定した. 第 2-4 腰椎，橈骨幹部， 全身の骨塩量を計湘し，また腰椎，橈骨は正常女性対照の年齢による補正値，全身骨塩量は総脂肪量での補正值に て検討した。腰椎では stage や活動性，検查所見との差を認めなかった。しかし暁骨骨幹部や全身骨塩量は stage N 群が stage I - III群より低下し，また握力の低下に有意に相関して低下した．検查所見では，血清学的検査との 関係を認めなかったが, リンバ球サブセットの CD4 細胞の減少例, CD4+CD45RA 細胞の減少例, CD8+HLA・ DR 細胞の増加例で有意に低下することが示され，RAの osteoporosisに RA の自己免疫機転が関与することが示 唆された。

\section{I . 緒 言}

慢性関節りウマチ（以下 RA）では関節周囲以外の全 身性の骨粗箖症の報告もされ, その進展に RA の活動
性やステロイド治療の関与が考えられているい RA 関節液にて CD4 細胞の低下, HLA-DR 陽性 T 細 胞の堌加)が示され病態との関係が注目されている。 れわれは, dual energy X-ray absorptiometry（以下

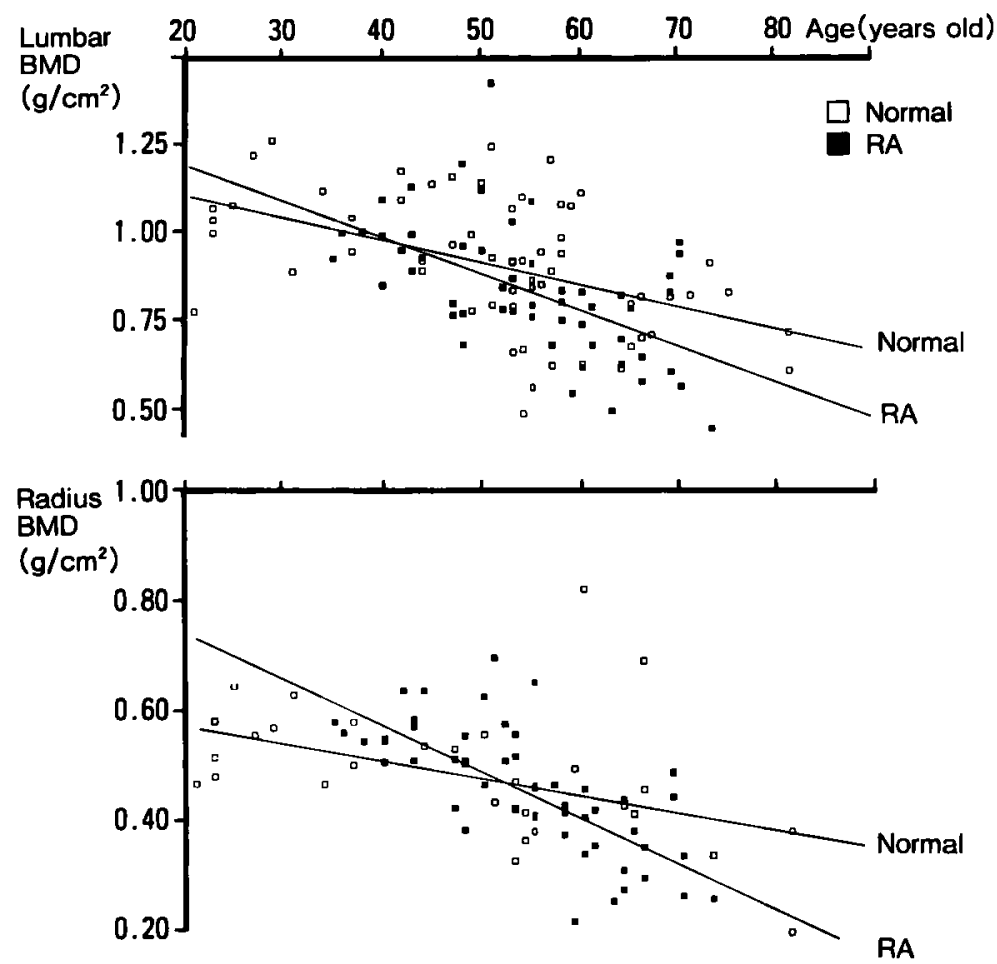

图 1 Correlation rate between bone mineral density and age Normal

lumbar : correlation rate $=-0.481^{* *}, y=-0.0063 x+1.233$

radius : correlation rate $=-0.442^{* *}, y=-0.0029 x+0.628$

RA (rheumatoid arthritis)

lumbar: correlation rate $=-0.550^{* *}, y=-0.0101 x+1.389$

radius : correlation rate $=-0.712^{* *}, y=-0.0082 x+0.903$

$* * \mathrm{p}<0.01$ statistical significance 


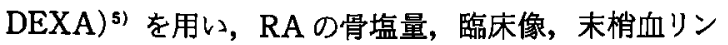
パ球サブセットの関係を調べた.

\section{II. 万法}

対象は 1987 年アメリカリウマチ協会基準を満たす女 性 RA 53 例（54.7 \pm 10.1 歳（平均士標準偏差：以下 同様))である．骨塩量は Norland 社 XR-26 を用い, 撓骨遠位端より $1 / 3$ の骨幹部，第 2 -第 4 全腰椎, 全身 骨塩量について検討した. 橈骨・腰椎は, 60 例健常人 女性の年齢（51.7 \pm 14.2 歳）と骨塩量の一次式による 補正値も検討した（図 1 ). 全身骨塩量 (TBM) は脂 肪量で除した補正值（TBM/TL）も検討した.

検討は血沈, 関節点数, 朝のこわばり時間, 握力に よる Lansbury's index, CRP, へモグロビン值, RAPA の対数值, $\gamma$ グロブリン值との単相関係数を統 計学的に解析した. prednisolone 治療は 12 例（全例 2 年以上, 経過中最大 $10 \mathrm{mg} /$ 日）で認め治療の有無, 投与量との相関も検討した。リンパ球サブセットは全 血直接法による二重染色 ${ }^{6,7)}$ で CD4（leu $3 \mathrm{a} ：$ Becton Dickinson 社) + CD45RA (2 H 4; Coulter 社), CD4 + HLADR (OKDR : Ortho 社), CD8 (leu 2 a) +HLADR, CD19 (leu 12) を調べ，18 例の健常人 data と比較した.

\section{III. 結 果}

RA 症例全体では, 骨塩量は腰椎 $0.835 \pm$ 0.186 (53), 橈骨 $0.460 \pm 0.113$ (51) と, 健常人腰 椎 $(0.907 \pm 0.186(60))$, 枿骨 $(0.482 \pm 0.116(34))$ より有意に低值を示した，RA，健常人ともに骨塩量と 年齢は $1 \%$ の危険率で負の相関を示した（図 1). 共分 散分析では橈骨骨塩量と年齢の回帰直線の傾き值が RA と健常群に $1 \%$ の危険率で有意差を認め，RA では健常 人より年跉による骨塩量の低下が顕著であった。

痽病期間は骨塩量との相関を認めなかった。 Lansbury's index は全身骨塩量と負の相関傾向を示し, 㨋力点 数は橈骨骨塩量 $\left(-0.34^{*}\right.$, 年齢補正 $\left.-0.35^{*}\right)$ や $\mathrm{TBM} / \mathrm{TL}\left(-0.41^{*}\right)$ と有意の負の相関を示した $\left(^{*}\right.$ ： $\mathrm{p}<0.05, * *: \mathrm{p}<0.01$ ：以下同様). stage $\mathrm{V}$ 群が stage I-III群より腰椎, 暁骨, 全身骨塩量ともに低値 の傾向を示し, 関節病変と骨粗裝症の相関関係が示さ れた(表 1 ).

骨塩量と各種炎症反応, 免疫グロブリン值, RAPA, 血清カルシウム值との有意の関係は認めなかった，ス テロイド使用の有無, 使用量との相関も示さなかった (表 2 ).

RAのリンパ球サブセットでは, 健常人より有意に $\mathrm{CD} 3$ 細胞, CD8 細胞, CD4+CD45RA 細胞の減少,

表 1 Correlation of bone mineral density and clinical data in rheumatoid arthritis

\begin{tabular}{|c|c|c|c|c|c|c|c|}
\hline \multirow[b]{2}{*}{ (n) } & & \multicolumn{2}{|c|}{$\operatorname{BMD}\left(\mathrm{g} / \mathrm{cm}^{2}\right)$} & \multicolumn{2}{|c|}{ corrected BMD (\%) } & \multirow{2}{*}{$\begin{array}{c}\text { TBM } \\
\left(\mathrm{g} / \mathrm{cm}^{2}\right) \\
27\end{array}$} & \multirow{2}{*}{$\begin{array}{c}\text { TBM/TL } \\
27\end{array}$} \\
\hline & & $\begin{array}{c}\text { Lumbar } \\
53\end{array}$ & $\begin{array}{c}\text { Ladius } \\
51\end{array}$ & $\begin{array}{c}\text { Lumbar } \\
53\end{array}$ & $\underset{51}{\text { Radius }}$ & & \\
\hline age & $(54.7 \pm 10.1)$ & $-0.54^{* *}$ & $-0.71^{* *}$ & -0.26 & $-0.55^{* *}$ & $-0.49^{* *}$ & $-0.57^{* *}$ \\
\hline duration & $(10.8 \pm 8.0)$ & $\#<0.1$ & $\#<0.1$ & $\#<0.1$ & $\#<0.1$ & 0.19 & $\#<0.1$ \\
\hline height & $(152 \pm 5.7 \mathrm{~cm})$ & $0.31^{*}$ & $0.51^{* *}$ & 0.20 & $0.41^{* *}$ & $0.57^{* *}$ & 0.31 \\
\hline weight & $(49 \pm 6.8 \mathrm{~kg})$ & 0.22 & $0.31^{*}$ & 0.17 & 0.27 & $0.50^{* *}$ & 0.33 \\
\hline L.I. & $(45.8 \pm 26.4 \%)$ & $\#<0.1$ & $\#<0.1$ & $\#<0.1$ & $\#<0.1$ & -0.24 & -0.26 \\
\hline ESR & $3.6 \pm 33.7 \mathrm{~mm} / \mathrm{h})$ & $\#<0.1$ & -0.14 & $\#<0.1$ & -0.13 & -0.19 & -0.36 \\
\hline MS & $(4.8 \pm 9.8 \%)$ & $\#<0.1$ & $\#<0.1$ & $\#<0.1$ & $\#<0.1$ & -0.13 & $\#<0.1$ \\
\hline GS & $(15.2 \pm 6.8 \%)$ & -0.17 & $-0.34^{*}$ & -0.15 & $-0.35^{*}$ & -0.14 & $-0.41^{*}$ \\
\hline JS & $(14.7 \pm 9.5 \%)$ & $\#<0.1$ & $\#<0.1$ & $\#<0.1$ & $\#<0.1$ & $\#<0.1$ & $\#<0.1$ \\
\hline $\begin{aligned} & \text { stage } \text { I } \\
& \text { II, III }\end{aligned}$ & $\begin{array}{l}\text { mean } \\
\quad \pm S D\end{array}$ & $\begin{array}{l}0.847 \\
\pm 0.19\end{array}$ & $\begin{array}{l}0.469 \\
\pm 0.11\end{array}$ & $\begin{array}{l}94.8 \\
\pm 0.18\end{array}$ & $\begin{array}{l}100.1 \\
\pm 19.8\end{array}$ & $\begin{array}{l}1.780 \\
\pm 0.47\end{array}$ & $\begin{array}{l}6.508 \\
\pm 1.63\end{array}$ \\
\hline stage $\mathrm{IV}$ & $\begin{array}{l}\text { mean } \\
\quad \pm S D\end{array}$ & $\begin{array}{l}0.778 \\
\pm 0.18\end{array}$ & $\begin{array}{l}0.416 \\
\pm 0.12\end{array}$ & $\begin{array}{l}90.2 \\
\pm 20.0\end{array}$ & $\begin{array}{l}91.1 \\
\quad \pm 22.2\end{array}$ & $\begin{array}{l}1.333 \\
\pm 0.58\end{array}$ & $\begin{array}{l}4.267 \\
\pm 1.32\end{array}$ \\
\hline
\end{tabular}

$\#<0.1:-0.1<$ correlation rate $<0.1, *: \mathrm{p}<0.05,{ }^{* *}: \mathrm{p}<0.01$, statistical significance, BMD : bone mineral density, TBM : total bone mineral, TL : total lean mass, age, duration : years, L.I. : Lansbury's index, MS : morning stiffness score, GS : grasping score, JS : joint score 
表 2 Correlation of bone mineral density and laboratory data in rheumatoid arthritis

\begin{tabular}{|c|c|c|c|c|c|c|}
\hline \multirow{2}{*}{\multicolumn{3}{|c|}{$($ mean $\pm \mathrm{SD}(\mathrm{n}))$}} & \multicolumn{2}{|c|}{ corrected BMD (\%) } & \multirow{2}{*}{$\begin{array}{c}\text { TBM } \\
\left(\mathrm{g} / \mathrm{cm}^{2}\right) \\
(27)\end{array}$} & \multirow{2}{*}{$\begin{array}{c}\mathrm{TBM} / \mathrm{TL} \\
(27)\end{array}$} \\
\hline & & & $\underset{(53)}{\text { Lumbar }}$ & $\underset{(53)}{\text { Radius }}$ & & \\
\hline \multicolumn{2}{|l|}{ CRP } & $(1.4 \pm 1.4(53))$ & $\#<0.1$ & -0.15 & -0.18 & -0.34 \\
\hline $\mathrm{Hb}$ & & $11.5 \pm 1.7 \mathrm{~g} / \mathrm{d} l(53))$ & $\#<0.1$ & 0.13 & 0.14 & 0.28 \\
\hline RAPA & & & 0.17 & $\#<0.1$ & $\#<0.1$ & -0.17 \\
\hline \multicolumn{2}{|c|}{$\gamma$ globulin } & $(1.8 \pm 1.8 \mathrm{~g} / \mathrm{d} l(53))$ & 0.12 & $\#<0.1$ & -0.14 & $-0.40^{*}$ \\
\hline $\operatorname{IgA}$ & & $99 \pm 117 \mathrm{mg} / \mathrm{d} l(53))$ & 0.18 & 0.22 & 0.23 & 0.11 \\
\hline \multicolumn{2}{|l|}{ IgG } & $24 \pm 648 \mathrm{mg} / \mathrm{d} l(53))$ & 0.13 & 0.18 & $\#<0.1$ & $\#<0.1$ \\
\hline \multicolumn{2}{|l|}{$\operatorname{IgM}$} & $196 \pm 99 \mathrm{mg} / \mathrm{d} l(53))$ & 0.16 & $0.35^{*}$ & 0.23 & $\#<0.1$ \\
\hline \multicolumn{2}{|c|}{ s-calcium } & $.9 \pm 0.5 \mathrm{mg} / \mathrm{d} l(53))$ & $\#<0.1$ & 0.10 & 0.05 & 0.13 \\
\hline \multicolumn{2}{|c|}{ PSL } & $1 \pm 2.0 \mathrm{mg} / \mathrm{day}(53))$ & $\#<0.1$ & -0.13 & -0.08 & 0.14 \\
\hline \multirow[t]{3}{*}{ PSL } & $\begin{array}{l}(+) \\
(12)\end{array}$ & $\begin{array}{l}\text { mean } \\
\pm S D\end{array}$ & $\begin{array}{l}91.8 \\
\pm 15.0\end{array}$ & $\begin{array}{l}92.9 \\
\pm 16.7\end{array}$ & $\begin{array}{l}1.688 \\
\pm 0.26\end{array}$ & $\begin{array}{l}6.400 \\
\pm 1.29\end{array}$ \\
\hline & $\begin{array}{l}(-) \\
(41)\end{array}$ & $\begin{array}{l}\text { mean } \\
\quad \pm S D\end{array}$ & $\begin{array}{l}94.3 \\
\pm 19.5\end{array}$ & $\begin{array}{l}99.3 \\
\pm 21.6\end{array}$ & $\begin{array}{l}1.747 \\
\pm 0.56\end{array}$ & $\begin{array}{l}6.200 \\
\pm 1.91\end{array}$ \\
\hline & & $($ mean $\pm S D(n))$ & $(41)$ & $(40)$ & $(22)$ & $(22)$ \\
\hline \multicolumn{2}{|l|}{$\mathrm{CD} 3$} & $(62.2 \pm 11.6 \%(39)$ & 0.21 & 0.30 & 0.33 & 0.32 \\
\hline \multicolumn{2}{|l|}{$\mathrm{CD} 4$} & $(42.1 \pm 9.2 \%(39))$ & 0.29 & $0.48^{* *}$ & $0.59^{* *}$ & $0.51^{*}$ \\
\hline \multicolumn{2}{|c|}{ CD 8} & $(20.3 \pm 7.0 \%(39)$ & -0.22 & -0.25 & -0.35 & -0.37 \\
\hline \multicolumn{2}{|c|}{$\mathrm{CD} 4 / 8$} & $(2.48 \pm 1.69(39)$ & 0.17 & 0.18 & $0.45^{*}$ & $0.45^{*}$ \\
\hline \multicolumn{2}{|c|}{$\mathrm{CD} 4+\mathrm{CD} 45 \mathrm{RA}$} & $\left(21.1 \pm 8.9 \%(38)^{\#)}\right.$ & $0.39^{*}$ & $0.59^{* *}$ & $0.55^{* *}$ & $0.54^{* *}$ \\
\hline \multicolumn{2}{|c|}{$\mathrm{CD} 4+\mathrm{HLA} \cdot \mathrm{DR}$} & $(4.2 \pm 2.6 \%(38)$ 骍) & $\#<0.1$ & $-0.32^{*}$ & -0.24 & -0.22 \\
\hline \multicolumn{2}{|c|}{$\mathrm{CD} 8+\mathrm{HLA} \cdot \mathrm{DR}$} & $(6.1 \pm 4.4 \%(38)$ \#) & -0.27 & $-0.34^{*}$ & -0.41 & -0.41 \\
\hline \multicolumn{2}{|c|}{ CD $19(B)$} & $(19.6 \pm 10.3 \%(38)$ & $\#<0.1$ & 0.11 & $\#<0.1$ & $\#<0.1$ \\
\hline
\end{tabular}

$\#<0.1:-0.1<$ correlation rate $<0.1, *: p<0.05,{ }^{* *}: p<0.01$, statistical significance, $\#: \mathrm{p}<0.05, \#: \mathrm{p}<0.01$, statistical defference from data of 18 normal controls (CD $3:$ $71.9 \pm 7.3 \%, \mathrm{CD} 4: 41.8 \pm 5.3 \%, \mathrm{CD} 8: 29.9 \pm 4.4 \%, \mathrm{CD} 4 / 8: 1.4 \pm 0.4, \mathrm{CD} 4+\mathrm{CD} 45 \mathrm{RA}:$ $24.9 \pm 5.1 \%, \mathrm{CD} 4+\mathrm{HLA} \cdot \mathrm{DR}: 2.2 \pm 0.7 \%: \mathrm{CD} 8+\mathrm{HLA} \cdot \mathrm{DR}: 2.9 \pm 2.2 \%, \mathrm{CD} 19: 13.5 \pm$ $3.9 \%)$, SD : standard deviation, BMD : bone mineral density, TBM : total bone mineral, TL : total lean mass, $\mathrm{Hb}:$ Hemoglobin, RAPA : log(RAPA titer), s-calcium : calsium concentration in serum, PSL : prednisolone

$\mathrm{CD} 4+\mathrm{HLA} \cdot \mathrm{DR}$ 細胞, CD $8+\mathrm{HLA} \cdot \mathrm{DR}$ 細胞, B 細胞, $\mathrm{CD} 4 / 8$ 比の増加を認めた. $\mathrm{RA}$ の $\mathrm{CD} 4$ 細胞は握 力 $\left(-0.34(54)^{* *}\right), \mathrm{IGg}\left(-0.34(61)^{* *}\right)$ と, $\mathrm{CD} 4+\mathrm{CD} 45 \mathrm{RA}$ 細胞は年齢 $\left(-0.32(60)^{*}\right)$, 握力 $\left(-0.31(58)^{*}\right)$ と CD8+HLA $\cdot \mathrm{DR}$ 細胞は年齢 $\left(0.27(60)^{*}\right), \operatorname{RAPA}\left(0.303(60)^{*}\right)$ との相関を認 めたが, 灰病期間, stage, 活動性, ステロイドなどと の相関関係は認めなかった。骨塩量では橈骨, 全身骨 塩量が CD4 細胞, CD4 +CD45RA 細胞と正の相関, $\mathrm{CD} 8+\mathrm{HLA} ・ \mathrm{DR}$ 細胞と負の相関を示し，この RA に 認めるリンパ球異常が骨塩量の低下と関係することが 示された（表 2 )。

\section{V. 考 案}

女性 RA 患者について，過去の報告 ${ }^{1 \sim 3,5)}$ に従い関節 近傍以外の骨塩量を橈骨遠位 $1 / 3$ 骨幹部, 腰椎, 全身 について DEXA 法で調べた. 腰椎, 暁骨ともに RAで は加齢による低下が顕著であった。臨床所見では, 腰 椎骨塩量との関係を認めなかったが, 橈骨・全身骨塩 量は stage の進展例，握力の低下例，CD4+CD45RA 細胞の低下例, CD48+HLA・DR 細胞の増加例で低 下した. RAの関節近傍の osteoporosis は stage 分類 の基準でもあるが，今回検討した関節部から離れた橈 骨骨幹部骨塩量の低下も，全身骨塩量の低下もRAの 病態としての osteoporosisを反映した. DEXA 法によ 
る骨塩量は RA の進展度の指標の一つとなるものと考 えられた。

加齢により骨塩量の低下が示されたことは, 閉経”の 影響も大きい。また䍜病期間との関係は年齢補正の影 響が無視できないものと思われる。われわれは比較的 単純に健常人年齢の一次式の検量線にて補正したが, 解析法についてもなお検討が必要と思われた。

ステロイドはRAの osteoporosisの原因として注目 されていた ${ }^{1,22}$. 最近では少量ステロイドでは骨塩量が 低下しない報告3もある.われわれの検討はステロイド 治療例が 12 例と少ないためさらに詳細な検討が必要と 思われた. RAの osteoporosisの原因として行動の低 下2)も重要な要因である。これは Lansbury's indexの 中では握力点数によく反映され，骨塩量との有意な相 関を認めた。

骨塩量の臨床免疫学的な検討は rheumatoid factor ${ }^{2)}$ が報告されている．われわれが RA で認めた末梢血り ンパ球サブセット異常と骨塩量の相関は，それぞれが

文

1) Kennedy, A.C., Smith, D.A., Antonand, H.C. et al. : Generalized and localized bone loss in patients with rheumatoid arthritis. Scand. J. Rheum., $4:$ 209 215, 1975.

2) Reid, D.M., Kennedy, N.S.J., Smith, M.A. et al. : Total body calcium in rheumatoid arthritis: effects of disease activity and corticosteroid treatment. B. Med. J., 285 : 330 332, 1982.

3) Sambrook, P.N., Cohen, M.L., Eisman, J.A. et al. : Effects of low dose corticosteroids on bone mass in rheumatoid arthritis. Ann. Rheum. Dis., 48: 535 538, 1989.

4) Reme, T., Portier, M., Frayssinoux, F. et al. : $\mathrm{T}$ cell receptor expression and activation of 活動性・stage・自己抗体，ステロイドとの相関関係に そしく間接的な要因の影響は否定され，osteoporosis の進展に自己免疫機転の関与が示唆された.

RA の重症度と末梢血リンパ球サブセットはなお一致 した見解がない4.7). しかし，活性化 cytotoxic cell で ある CD8+HLA・DR 細胞の増加や suppressor inducer 機能を有する CD4 +CD45RA 細胞の低下は primary Sjögren's syndromeの進展, lupus 腎炎やその 活動性との相関から臨床免疫学的な有用性 ${ }^{6,7)}$ が示され ている.

組織学的には RA 関節内4)では CD4+CD45RA の低 下, CD8+HLA ・ DR の増加が認められ, 骨破壊に関 与する IL 1, TNF $\alpha^{8)}$ の増加との関係が注目されてい る.われわれの今回の骨塩量との臨床的検討もこれら の報告を支持するものであるが，その細胞免疫学的な 検討は，今後の研究に期待したい。DEXA 法による骨 塩量の検討は, 単に osteoporosis に限らず RA の病態 を考える有用な手がかりとなるものと思われた.

献

synovial lymphocyte subsets in patients with rheumatoid arthritis. Arth. Rheum., 33: 485 $\sim 492,1990$.

5）福永仁夫・友光達志・森川陸司：骨塩定量の意 義. DEXA 法. 臨放, $35: 41 \sim 48,1990$.

6）渡部一郎・佐川 昭・中林 透 - 他：Primary Sjögren 症候群における末梢血 HLA-DR 陽性 T細胞, CD45R 陽性 CD4 細胞の複床的検討. リウマチ, $30: 181 \sim 189,1990$.

7）渡部一郎・種市幸二・芝木秀俊：慢性リウマチ の末梢血 HLA-DR 陽性 T cell と HLA-DRw9 表現型との関係. リウマチ科, $2: 288 \sim 299$, 1989.

8）伊藤潤平・沢井高志：RAにおける軟骨・骨破 壊. The Bone, 4:33 39, 1990. 